\title{
In search of Parkinson's disease biomarkers - is the answer in our mouths? A systematic review of the literature on salivary biomarkers of Parkinson's disease
}

\author{
Monika Figura, Andrzej Friedman \\ Department of Neurology, Faculty of Health Science, Medical University of Warsaw, Warsaw, Poland
}

\begin{abstract}
The identification of reliable biomarkers of Parkinson's disease (PD) is a pivotal step in the introduction of causal therapies. Saliva is a biofluid which may be involved in synuclein pathology in PD. We have reviewed current studies on salivary proteins and compounds in PD patients and healthy controls, and their potential application as biomarkers.

A systematic literature search of the Pubmed and Scopus databases was performed. A total of 198 studies were screened, of which 20 were included in our qualitative analysis. We conclude that the oligomeric form of salivary alpha synuclein is higher in PD patients, and that this may serve as a potential biomarker of PD. Salivary DJ-1 concentrations fail to differentiate PD patients from controls. Other enzymes and substances (heme oxygenase-1, nitric oxide, acetylcholinesterase) have been assessed in single studies. Salivary cortisol levels are higher in PD than in healthy subjects. Further validation of these findings is needed. Saliva may be a promising source of biomarkers in PD.
\end{abstract}

Key words: Parkinson's disease, saliva, biomarker, neurodegeneration

(Neurol Neurochir Pol 2020; 54 (1): 14-20)

\section{Introduction}

Numerous studies have been conducted with the aim of identifying potential biomarkers for Parkinson's disease (PD), the second most common neurodegenerative disorder [1]. Current research on causative treatment for PD is hindered by a lack of biomarkers and the recent introduction of potentially disease-modifying medications. The two most commonly assessed physiological fluids that are used for the detection of markers of PD are cerebrospinal fluid and blood. Acquiring samples of these two fluids causes at least some discomfort and pain to the patient. Saliva has advantages over these fluids: a relatively safe and less invasive collection process, and low levels of blood contamination, as well as many others.

Saliva production was initially investigated in PD with regard to drooling. It was already mentioned in the very first description of PD by James Parkinson in his "An Essay on the Shaking Palsy" [2]. Numerous studies were conducted to investigate the pathomechanism behind this phenomenon, revealing that: 1 . Drooling is in fact caused by dysphagia rather than by higher-than-normal production of saliva in PD patients; and 2. Total saliva production in PD subjects may actually be lower than in healthy controls [3-7]. Some of these studies have indicated that saliva composition is different in PD patients than in healthy subjects. A meta-analysis by Masters et al. proved that total salivary protein concentration in PD patients is higher compared to controls [8]. Some authors have suggested that this may be caused by an over-secretion of proteins by the submandibular, sublingual and parotid glands $[8,9]$.

This interest in studies of saliva in PD is justified by recent histopathological discoveries, especially multiorgan involvement of PD-related a-synucleinopathy [10]. Submandibular and minor salivary glands have established involvement in $a$-synuclein pathology $[11,12]$. Needle core biopsies of submandibular glands of PD patients have confirmed the presence of Lewy-type a-synucleinopathy in about $75 \%$ of cases, with even higher rates of positive findings in post-mortem histopathological studies [13-15]. 
Therefore, saliva, as a product of these glands, may reflect their involvement in PD pathology. Especially unstimulated saliva seems to be of interest, as it is produced mainly by submandibular glands, as opposed to stimulated saliva which is produced by parotid glands.

The aim of this study was to summarise current findings on salivary biomarkers of $\mathrm{PD}$, as well as to identify the most promising targets for future validation.

\section{Methods}

We searched the PubMed and Scopus databases using the key words 'Parkinson's disease', 'parkinsonism' and 'saliva' to identify publications in this area from 1 January 2000 up to 7 September 2019. The search was conducted in accordance with PRISMA guidelines for systematic review [16]. We included only studies in English. We assessed each of the 198 unique abstracts we found. We then considered only original publications pertaining to human saliva biochemical properties and saliva sample collection. We excluded review papers and meta-analyses. Additionally, we excluded from our systematic review studies assessing microbiome and oral hygiene of the mouth in PD, mechanisms of dysphagia, and treatment of hypersalivation and other clinical interventions, focusing solely on unique changes in saliva composition related to $\mathrm{PD}$. We also excluded studies assessing only non-specific aspects of salivary composition in PD, such as electrolyte levels or total protein concentration. These restrictions reduced the number of reviewed publications to 20. The PRISMA flowchart of our selection process is presented in the section supplementary material 1.

To deal with the heterogenicity of findings, we further divided the studies into those assessing concentrations of $\alpha$-synuclein, DJ-1, biomarkers of non-motor symptoms, and other salivary biomarkers.

\section{Results}

In total, we identified 20 studies on salivary biomarkers of $\mathrm{PD}$, its progression or non-motor symptoms. Two papers report measurements of both salivary $\alpha$-synuclein and DJ-1 $[17,18]$.

\section{Salivary a -synuclein}

$a$-synuclein is a presynaptic neuronal protein with robust expression in Lewy bodies [19-21]. Its detection is currently the gold standard in neuropathological confirmation of PD. It has also been extensively investigated as a potential biomarker.

We identified eight studies in which the authors measured levels of $a$-synuclein and its sub-forms in the saliva of PD patients and controls. A summary of the findings is presented in Table 1. Two studies originate from the same centre; however, the patients were recruited separately, and over different periods of time [22, 23]
Reports on concentrations of total $\alpha$-synuclein in PD versus controls are inconsistent. In three papers, the authors report lower concentrations of total salivary $a$-synuclein in PD patients compared to controls [22-24]. In five other studies, no significant changes in total salivary $a$-synuclein were found [17, 18, 25-27]

In four studies including a total of $435 \mathrm{PD}$ patients and 247 controls, the authors measured concentrations of the oligomeric form of $\alpha$-synuclein separately. In all of these studies, higher levels of oligomeric $\alpha$-synuclein were observed in the saliva of PD patients than in controls [22, 23, 26, 27].

One study also assessed concentrations of phosphorylated a-synuclein, but no difference was found between PD saliva and healthy controls [27].

\section{Salivary DJ-1}

The functions of the DJ-1 protein include acting as an antioxidant, transcriptional co-activator, and molecular chaperone. DJ-1 mutations account for 1-2\% of early onset cases of PD [28]. Concentrations of salivary DJ-1 in PD patients were assessed in four papers $[17,18,29,30]$. These are summarised in Table 2. Although some authors reported higher concentrations of saliva DJ-1 in PD patients, these results were not confirmed after correction for total salivary protein concentration, which is also higher in PD patients [9, 29, 30]. A study by Stewart et al. assessed the liquid and cellular components of saliva (cheek epithelial cells) separately, but again no differences between PD patients and healthy controls were found [18].

Two studies reported higher DJ-1 levels in patients with more advanced PD. Kang et al. (2014) reported higher concentrations of DJ-1 in the saliva of PD patients with Hoehn and $\mathrm{Yahr}(\mathrm{H} \& \mathrm{Y})$ stage 4 compared to stages $1-3$. However, no correlations with Unified Parkinson's Disease Rating Scale (UPDRS) scores, treatment or disease duration were found. They also observed a weak positive correlation between DJ-1 concentrations and putamen nucleus uptake of ${ }^{99 \mathrm{~m}} \mathrm{Tc}$ TRODAT-1 in PD patients [26]. Masters et al. reported that adjusted DJ-1 levels correlated positively with disease severity measured with the Movement Disorders Society-UPDRS ( $\mathrm{p}$ $=0.019)[9]$.

\section{Salivary biomarkers of non-motor symptoms}

Findings on salivary biomarkers of non-motor symptoms in PD are summarised in Table 3.

Salivary cortisol levels were assessed in three studies as markers of non-motor symptoms: pain, depression and anxiety, and impulsive compulsive behaviours. Studies by Skogar et al. and Costa et al. reported significantly higher levels of total salivary cortisol in PD patients compared to healthy controls $[31,32]$. Higher levels of cortisol correspond to PD patients with higher scores on the Hamilton Anxiety Rating Scale and the Hamilton Depression Rating Scale [32]. Pain and motor dysfunction does not affect cortisol levels in PD patients [31]. 
Table 1. Summary of studies assessing salivary a-synuclein levels in PD patients

\begin{tabular}{|c|c|c|c|c|c|c|}
\hline Author & $\begin{array}{l}\text { Sample } \\
\text { size }\end{array}$ & $\begin{array}{l}\text { Method } \\
\text { of collection }\end{array}$ & $\begin{array}{c}\text { Method of } \\
\alpha \text {-synuclein } \\
\text { quantification }\end{array}$ & Total $\alpha$-synuclein & $\begin{array}{l}\text { Oligomeric } \\
\alpha \text {-synuclein }\end{array}$ & Additional findings \\
\hline Cao et al. 2019 & $\begin{array}{l}\mathrm{PD} n=74 \\
\mathrm{HC} n=60\end{array}$ & $\begin{array}{l}\text { Unstimulated, } \\
\text { saliva, drool into } \\
\text { a } 50 \mathrm{ml} \text { vial }\end{array}$ & ECL assay & $\begin{array}{c}\text { No difference } \\
\text { between PD and } \\
\text { HCs }\end{array}$ & $\begin{array}{l}\text { Higher in PD than in } \\
\text { HCs (median } 7.03 \mathrm{pg} / \\
\text { /ng vs. } 0.92 \mathrm{pg} / \mathrm{ng} \text {; } \\
\mathrm{p}<0.001 \text { ) }\end{array}$ & $\begin{array}{c}\text { Exosomes are present } \\
\text { in saliva } \\
\text { No difference in } \\
\text { phosphorylated } \\
\text { a-synuclein between } \\
\text { PD and HC } \\
\text { No significant correla- } \\
\text { tion with H\&Y stage }\end{array}$ \\
\hline $\begin{array}{l}\text { Vivacqua et al. } \\
2019\end{array}$ & $\begin{array}{l}P D n=100 \\
P S P n=20 \\
H C n=80\end{array}$ & $\begin{array}{l}\text { Unstimulated saliva, } \\
\text { drool into a } 50 \mathrm{ml} \\
\text { vial }\end{array}$ & ELISA & $\begin{array}{l}\text { Lower in PD than } \\
\text { HCs }(7.104 \pm 5.122 \\
\rho g / \mathrm{m} \text { vs. } 28.444 \pm \\
25.877 \rho g / \mathrm{m} ; \\
p<0.05)\end{array}$ & $\begin{array}{l}\text { Higher in PD than in } \\
\mathrm{HCs}(0.893 \pm 1.949 \mathrm{ng} / \\
/ \mathrm{ml} \text { vs. } 0.217 \pm 0.191 \\
\mathrm{ng} / \mathrm{ml} ; \mathrm{p}<0.05)\end{array}$ & $\begin{array}{l}\text { Total a-synuclein in } \\
\text { PSP higher than in PD }\end{array}$ \\
\hline $\begin{array}{l}\text { Vivacqua et al. } \\
2016\end{array}$ & $\begin{array}{l}\mathrm{PD} n=60 \\
\mathrm{HC} n=40\end{array}$ & $\begin{array}{l}\text { Unstimulated saliva, } \\
\text { drool into a } 50 \mathrm{ml} \\
\text { vial }\end{array}$ & ELISA & $\begin{array}{l}\text { Lower in PD than } \\
\text { HCs }(5.08 \\
\pm 3.01 \mathrm{pg} / \mathrm{ml} \mathrm{vs} . \\
31.3 \pm 22.4 \mathrm{pg} / \mathrm{ml} \\
\mathrm{p}<0.01)\end{array}$ & $\begin{array}{l}\text { Higher in PD than in } \\
\mathrm{HCs}(1.062 \pm 0.266 \mathrm{ng} / \\
/ \mathrm{ml} \text { vs. } 0.498 \pm 0.203 \\
\mathrm{ng} / \mathrm{ml} ; \mathrm{p}<0.01)\end{array}$ & $\begin{array}{l}\text { Mild positive corre- } \\
\text { lation between total } \\
\text { alpha-synuclein and } \\
\text { disease duration, H\&Y } \\
\text { and MDS-UPDRS total } \\
\text { score }\end{array}$ \\
\hline Devic et al. 2011 & $\begin{array}{l}P D n=24 \\
H C n=25\end{array}$ & $\begin{array}{l}\text { Unstimulated saliva, } \\
\text { drool into a } 50 \mathrm{ml} \\
\text { vial }\end{array}$ & Luminex assay & $\begin{array}{l}\text { No difference be- } \\
\text { tween PD and HC }\end{array}$ & Not measured & $\begin{array}{l}\text { Trend for } a \text {-synuclein } \\
\text { to decrease and DJ-1 } \\
\text { to increase in PD vs HC }\end{array}$ \\
\hline $\begin{array}{l}\text { Goldman et al. } \\
2018\end{array}$ & $\begin{array}{l}\mathrm{PD} n=22 \\
\mathrm{HC} n=26\end{array}$ & Not mentioned & ELISA & $\begin{array}{l}\text { No difference be- } \\
\text { tween PD and HC }\end{array}$ & Not measured & \\
\hline $\begin{array}{l}\text { Stewart et al. } \\
2014\end{array}$ & $\begin{array}{l}\mathrm{PD} n=24 \\
\mathrm{HC} n=198\end{array}$ & $\begin{array}{c}\text { Unstimulated saliva, } \\
\text { drool into a } 50 \mathrm{ml} \\
\text { vial }\end{array}$ & Not specified & $\begin{array}{l}\text { No difference be- } \\
\text { tween PD and HC }\end{array}$ & Not measured & $\begin{array}{l}\text { DJ-1 and a-synuclein } \\
\text { in the cellular com- } \\
\text { ponent of saliva - as- } \\
\text { sessed separately }\end{array}$ \\
\hline $\begin{array}{l}\text { Al-Nimer, Msha- } \\
\text { tat, and Abdulla } \\
2014\end{array}$ & $\begin{array}{l}P D n=20 \\
H C n=20\end{array}$ & $\begin{array}{l}\text { Unstimulated saliva, } \\
\text { details of collection } \\
\text { not mentioned }\end{array}$ & ELISA & $\begin{array}{l}\text { Lower in PD than } \\
\text { in } \mathrm{HC}(65 \pm 52.2 \mathrm{pg} / \\
\quad / \mathrm{ml} \mathrm{vs.} 314.01 \pm \\
435.9 \mathrm{pg} / \mathrm{ml} \\
\mathrm{p}<0.02)\end{array}$ & Not measured & \\
\hline Kang et al. 2016 & $\begin{array}{l}P D n=201 \\
H C n=67\end{array}$ & $\begin{array}{l}\text { Unstimulated saliva, } \\
\text { details of collection } \\
\text { not mentioned }\end{array}$ & ELISA, HPLC & $\begin{array}{l}\text { No difference be- } \\
\text { tween PD and HC }\end{array}$ & $\begin{array}{l}\text { Higher in PD than in } \\
\text { HCs (numbers not } \\
\text { specified) }\end{array}$ & $\begin{array}{l}\text { Significant differences } \\
\text { in oligomer/total } \\
\text { a-synuclein ratio in } \\
\text { each H\&Y stage }\end{array}$ \\
\hline
\end{tabular}

PD — Parkinson's disease, HC — healthy controls, PSP — progressive supranuclear palsy, H\&Y — Hoehn and Yahr stage, UPDRS — Unified Parkinson's disease rating scale, ECL — electrochemiluminescence assay, ELISA - enzyme-linked immunosorbent assay, HPLC - high pressure liquid chromatography

In a study by Djamshidian et al., attenuated cortisol levels were also correlated with increased risk taking in PD patients with impulsive compulsive behaviours [33].

Saliva melatonin levels in PD and healthy subjects were assessed with regards to their role in circadian phase and habitual sleep onset time. No significant differences were found between unmedicated PD patients and healthy controls. Interestingly, the authors indicate the role of dopaminergic treatment in melatonin secretion, with the medicated PD group showing double the melatonin AUC of the unmedicated group [34].

One study identified reduced salivary substance P (SP) levels as an early biomarker of dysphagia in PD [35]. Saliva
SP concentrations were significantly lower in PD patients with dysphagia compared to non-dysphagic patients $(9.644 v s$. $17.591 \mathrm{pg} / \mathrm{mL} ; \mathrm{p}=0.001)$. The authors conclude that reduced SP levels may serve as an early dysphagia marker.

\section{Other salivary compounds measured in PD}

Fedorova et al. reported increased salivary acetylcholinesterase activity in PD. A total of $30 \mathrm{PD}$ patients and 49 controls were involved. A colorimetric method was used to measure enzyme activity. Due to a significant overlap in results between $\mathrm{PD}$ and control groups, the authors declared it to be a marker of parasympathetic denervation rather that a biomarker of PD [36]. 
Table 2. Summary of studies assessing salivary DJ-1 levels in PD patients

\begin{tabular}{|c|c|c|c|c|c|}
\hline Author & $\begin{array}{l}\text { Sample } \\
\text { size }\end{array}$ & Method of collection & $\begin{array}{l}\text { Method of DJ-1 } \\
\text { quantification }\end{array}$ & DJ-1 concentration & Additional findings \\
\hline Devic et al. 2011 & $\begin{array}{l}P D n=24 \\
H C n=25\end{array}$ & $\begin{array}{l}\text { Unstimulated saliva, drool } \\
\text { into a } 50 \mathrm{ml} \text { vial }\end{array}$ & Luminex assay & $\begin{array}{l}\text { No significant difference } \\
\text { between PD and HC }\end{array}$ & $\begin{array}{l}\text { DJ-1 concentration did not } \\
\text { correlate with UPDRS score }\end{array}$ \\
\hline Kang et al. 2014 & $\begin{array}{c}P D=285 \\
H C=91\end{array}$ & $\begin{array}{l}\text { Unstimulated saliva, drool } \\
\text { into a } 15 \mathrm{ml} \text { vial }\end{array}$ & Luminex assay & $\begin{array}{l}\text { No significant difference } \\
\text { between PD and HC }\end{array}$ & $\begin{array}{c}\text { DJ-1 concentration did not } \\
\text { correlate with UPDRS score; } \\
\text { DJ-1 levels in H\&Y-4 stage of } \\
\text { PD was higher than those in } \\
\text { H\&Y 1-3 stage }\end{array}$ \\
\hline $\begin{array}{l}\text { Masters et al. } \\
2015\end{array}$ & $\begin{array}{l}\mathrm{PD} n=16 \\
\mathrm{HC} n=22\end{array}$ & $\begin{array}{l}\text { Unstimulated saliva, drool } \\
\text { into a } 20 \mathrm{ml} \text { tube }\end{array}$ & Immunoblotting & $\begin{array}{l}\text { Higher in PD than in HC }(0.84 \\
\text { vs. } 0.42 \mu \mathrm{g} / \mathrm{ml}, \mathrm{p}=0.001) ; \\
\text { after adjusting for total } \\
\text { protein concentration no } \\
\text { difference }\end{array}$ & $\begin{array}{l}\text { Adjusted value for salivary } \\
\text { DJ-1 concentration was posi- } \\
\text { tively correlated with UPDSS }\end{array}$ \\
\hline $\begin{array}{l}\text { Stewart et al. } \\
2014\end{array}$ & $\begin{array}{l}\mathrm{HC} n=198 \\
\mathrm{PD} n=24\end{array}$ & $\begin{array}{l}\text { Unstimulated saliva, drool } \\
\text { into a } 50 \mathrm{ml} \text { vial, separa- } \\
\text { tion of cellular component } \\
\text { of saliva }\end{array}$ & Not specified & $\begin{array}{l}\text { No significant difference } \\
\text { between PD and HC }\end{array}$ & \\
\hline
\end{tabular}

PD - Parkinson's disease, HC - healthy controls, H\&Y - Hoehn and Yahr stage, UPDRS - Unified Parkinson's disease rating scale

A study by Huskić et al. analysed levels of salivary nitric oxide synthesis in the saliva of PD patients. A colorimetric method involving Griess reaction was used. The study included 16 PD patients and 16 healthy controls. The authors reported significantly lower salivary $\mathrm{NO}^{2}$ concentrations in $\mathrm{PD}$ patients than in healthy subjects $(5.02 \pm 0.36$ vs. $22.39 \pm 1.24, \mathrm{p}<0.0001)$. The importance of this study is limited by numerous external factors that may influence oral nitric oxide synthesis [37].

Song et al. reported higher salivary concentrations of heme oxygenase-1 in a group of $58 \mathrm{PD}$ patients versus 59 healthy controls $(7.38 \pm 0.95$ vs. $4.87 \pm 0.68 ; \mathrm{p}=0.03)$. ELISA and Western Blot methods were used. The authors noted higher salivary heme oxygenase- 1 concentrations in patients with early idiopathic PD (Hoehn and Yahr stage 1-2) [38].

A study by Bermejo-Pareja et al. focused primarily on biomarkers of Alzheimer's disease. However, 51 PD patients and 56 elderly healthy subjects were involved as controls versus 70 Alzheimer's disease patients. Levels of salivary and plasma beta-amyloid were assessed with the ELISA method. The study revealed no significant difference in salivary beta-amyloid concentrations between PD and healthy subjects [39].

Chuang et al. reported higher methylation levels of DNA in PD. Saliva samples were collected from 128 PD patients and 131 controls. DNA methylation data was generated using the Illumina Infinium array. Saliva analysis identified five significant CpG sites [40]. The authors reported that gene/pathway enrichment analysis showed enrichment for gene sets related to neuron differentiation and projection.

\section{Conclusions}

Based on the available studies of the salivary proteins in $\mathrm{PD}$, oligomeric $a$-synuclein is the most promising salivary biomarker of this disease. This is especially interesting when one considers that oligomeric forms of $a$-synuclein seem to be pivotal in the neurodegeneration process, mainly the formation of non-soluble deposits in PD [41]. a-synuclein oligomer levels have been described as being elevated in the cerebral cortex and brainstem of patients with idiopathic PD compared to age-matched healthy controls [42]. Increased concentrations of oligomeric forms of $\alpha$-synuclein in cerebrospinal and lacrimal fluid have also been indicated as potential biomarkers of PD [43, 44].

Other proteins involved in the PD pathomechanism - total a-synuclein and DJ-1 - fail to differentiate between PD and healthy controls. Two other salivary compounds - heme oxygenase-1 and nitric oxide - have been reported by authors as potentially differentiating between PD and healthy controls. These findings come from single studies and need further validation. Substance P seems to be a potential early biomarker of dysphagia. This is especially interesting in the context of respiratory disorders (also due to aspiration) as the leading cause of death in PD patients [45].

The great limitation in salivary research is the variability of saliva composition. It has been proven that even the type of saliva collected (stimulated or unstimulated) may influence its microbiome composition [46]. Our review revealed discrepancies between concentrations of proteins reported by different groups. This is probably caused by different protocols for the collection and processing of saliva, and raises concerns about the reproducibility of some findings. Vivacqua et al. hypothesised that differences in reported salivary $a$-synuclein concentrations may be caused by different conformations of the protein, resulting in unpredictable antigen-antibody binding [23]. A study by Hong et al. also emphasised the importance of blood contamination of body fluids. Higher 
Table 3. Summary of studies assessing salivary biomarkers of non-motor symptoms of PD

\begin{tabular}{|c|c|c|c|c|c|}
\hline Author & Sample size & $\begin{array}{l}\text { Non-motor } \\
\text { symptoms } \\
\text { assessed }\end{array}$ & $\begin{array}{l}\text { Compo- } \\
\text { und mea- } \\
\text { sured }\end{array}$ & Method & Results \\
\hline $\begin{array}{l}\text { Skogar et al. } \\
2011\end{array}$ & $\begin{array}{l}P D n=59 \\
H C n=608\end{array}$ & Pain & Cortisol & $\begin{array}{l}\text { Spectria }{ }^{\circledR} \text { Corti- } \\
\text { sol I }^{125} \text { radioim- } \\
\text { munoassay }\end{array}$ & $\begin{array}{l}\text { Morning cortisol concentration higher in PD than } \\
\qquad \text { HC group } \\
\text { Total cortisol secretion during day higher in PD } \\
\text { than HC (AUC } 112.8 \text { nmolh vs. } 81.1 \text { nmolh) } \\
\text { No significant correlations with age, gender, BMI, } \\
\text { duration of PD, H\&Y score, UPDRS III score, gait, } \\
\text { pain and cortisol concentrations }\end{array}$ \\
\hline Costa et al. 2019 & $\begin{array}{l}\mathrm{PD} n=18 \\
\mathrm{HC}=17\end{array}$ & $\begin{array}{l}\text { Anxiety, } \\
\text { depression }\end{array}$ & Cortisol & ELISA & $\begin{array}{l}\text { Higher in PD than HC ( } 972.5 \mathrm{pg} / \mathrm{ml} \text { vs. } 425 \mathrm{pg} / \mathrm{ml} \text {, } \\
\qquad \mathrm{p}=0.03 \\
\text { Positive correlation between cortisol and HAM-A } \\
\text { score }(r=0.46 ; p=0.02) \text {, and HAM-D score } \\
\qquad(r=0.09 ; p=0.02)\end{array}$ \\
\hline $\begin{array}{l}\text { Djamshidian et } \\
\text { al. } 2011\end{array}$ & $\begin{array}{c}P D n=28 \\
(P D I C B+n=15, \\
\text { PD ICB- } n=13) \\
H C n=14\end{array}$ & $\begin{array}{l}\text { Impulsive } \\
\text { compulsive } \\
\text { behaviour }\end{array}$ & Cortisol & $\begin{array}{c}\text { Immulite Immu- } \\
\text { noassay }\end{array}$ & $\begin{array}{l}\text { Higher daily salivary cortisol levels in PD ICB-pa- } \\
\text { tients compared to healthy controls but no differ- } \\
\text { ence between PD ICB+ patients and controls. }\end{array}$ \\
\hline $\begin{array}{l}\text { Bolitho et al. } \\
2014\end{array}$ & $\begin{array}{c}\mathrm{HC} n=27 \\
\text { PD } n=29 \text { (medicated } \\
\text { PD } n=16 ; \text { unmedica- } \\
\text { ted PD } n=13 \text { ) }\end{array}$ & $\begin{array}{l}\text { Sleep cycle } \\
\text { disturbances }\end{array}$ & Melatonin & $\begin{array}{l}\text { Double- } \\
\text {-antibody radio- } \\
\text { immunoassay }\end{array}$ & $\begin{array}{l}\text { Unmedicated PD vs. } \mathrm{HC} \text { - no difference in mela- } \\
\text { tonin concentration } \\
\text { Medicated PD group - greater } A U C \text { of melatonin } \\
\text { compared to unmedicated } P D(U=31 ; P=.001) \\
\text { and } H C(U=87 ; P=.001) \text {, respectively }\end{array}$ \\
\hline $\begin{array}{l}\text { Muhle et al. } \\
2018\end{array}$ & $\begin{array}{l}\text { PD } n=20 \text { (PD with } \\
\begin{array}{c}\text { dysphagia } n=10 ; P D \\
\text { without dysphagia } n \\
=10) \\
\text { No HC }\end{array}\end{array}$ & Dysphagia & $\begin{array}{c}\text { Substance } \\
P\end{array}$ & ELISA & $\begin{array}{l}\text { Saliva substance } P \text { concentrations significantly } \\
\text { lower in PD with dysphagia than PD without } \\
\text { dysphagia ( } 9.644 \text { vs. } 17.591 \mathrm{pg} / \mathrm{mL} ; \mathrm{p}=0.001)\end{array}$ \\
\hline
\end{tabular}

PD - Parkinson's disease, HC - healthy controls, H\&Y - Hoehn and Yahr stage, UPDRS - Unified Parkinson's disease rating scale, HAM-A - Hamilton Anxiety Rating Scale, HAM-D - Hamilton Depression Rating Scale

concentrations of both DJ-1 and a-synuclein may be falsely reported in contaminated samples [47]. Interestingly, while some studies did not observe a correlation of DJ-1 and $\alpha$-synuclein with age, others have reported decreases in $\alpha$-synuclein concentrations with advancing age $[18,26]$. Sex may also influence salivary composition, as DJ-1 has been reported to be slightly higher in men, while $\alpha$-synuclein was higher in women, in the study by Stewart et al. [18]. Another obstacle is the lack of a unified gold standard in terms of saliva collection protocol in biomarker research. Protocols differ in complexity. For some patients, collection may even cause distress and therefore influence salivary composition. Over 50\% of patients with PD report hyposalivation and/or xerostomia, which may exclude them from research [48].

Future prospects in salivary biomarker research include much more robust identification of proteins and peptides. Large-scale studies of proteome are possible due to the availability of mass-spectrometry techniques, and these methods are becoming increasingly accurate with the implementation of Orbitrap spectrometers. Future studies on biomarkers in PD should lead to the unification and improvement of methods for studies on salivary biomarkers of PD-related neurodegeneration.

\section{References}

1. Lau Lde, Breteler M. Epidemiology of Parkinson's disease. The Lancet Neurology. 2006; 5(6): 525-535, doi: 10.1016/s14744422(06)70471-9.

2. Parkinson J. An Essay on the Shaking Palsy: Sherwood, Neely, and Jones. ; 1817.

3. Potulska A, Friedman A, Królicki L, et al. [Swallowing disorders in Parkinson's disease]. Neurol Neurochir Pol. 2002; 36(3): 449-456, indexed in Pubmed: 12185801.

4. Proulx M, de Courval FP, Wiseman MA, et al. Salivary production in Parkinson's disease. Mov Disord. 2005; 20(2): 204-207, doi: 10.1002/ mds.20189, indexed in Pubmed: 15389996.

5. Cersósimo MG, Tumilasci OR, Raina GB, et al. Hyposialorrhea as an early manifestation of Parkinson disease. Auton Neurosci. 2009; 150(1-2): 150-151, doi: 10.1016/j.autneu.2009.04.004, indexed in Pubmed: 19419908.

6. Karakoc M, Yon MI, Cakmakli GY, et al. Pathophysiology underlying drooling in Parkinson's disease: oropharyngeal bradykinesia. Neurol 
Sci. 2016; 37(12): 1987-1991, doi: 10.1007/s10072-016-2708-5, indexed in Pubmed: 27613712.

7. Tumilasci OR, Cersósimo MG, Belforte JE, et al. Quantitative study of salivary secretion in Parkinson's disease. Mov Disord. 2006; 21(5): 660-667, doi: 10.1002/mds.20784, indexed in Pubmed: 16419045.

8. Masters JM, Bestwick J, Warner TT, et al. Systematic review and metaanalysis of salivary protein concentration in Parkinson's disease. Mov Disord. 2015; 30(14): 1971-1972, doi: 10.1002/mds.26462, indexed in Pubmed: 26583568.

9. Masters JM, Noyce AJ, Warner TT, et al. Elevated salivary protein in Parkinson's disease and salivary DJ-1 as a potential marker of disease severity. Parkinsonism Relat Disord. 2015; 21(10): 1251-1255, doi: 10.1016/j.parkreldis.2015.07.021, indexed in Pubmed: 26231472.

10. Gelpi E, Navarro-Otano J, Tolosa E, et al. Multiple organ involvement by alpha-synuclein pathology in Lewy body disorders. Mov Disord. 2014; 29(8): 1010-1018, doi: 10.1002/mds.25776, indexed in Pubmed: 24395122.

11. Del Tredici K, Hawkes CH, Ghebremedhin E, et al. Lewy pathology in the submandibular gland of individuals with incidental Lewy body disease and sporadic Parkinson's disease. Acta Neuropathol. 2010; 119(6): 703-713, doi: 10.1007/s00401-010-0665-2, indexed in Pubmed: 20229352.

12. Cersósimo MG, Perandones C, Micheli FE, et al. Alpha-synuclein immunoreactivity in minor salivary gland biopsies of Parkinson's disease patients. Mov Disord. 2011; 26(1): 188-190, doi: 10.1002/ mds.23344, indexed in Pubmed: 20836135.

13. Adler CH, Dugger BN, Hentz JG, et al. Peripheral Synucleinopathy in Early Parkinson's Disease: Submandibular Gland Needle Biopsy Findings. Mov Disord. 2016; 31(2): 250-256, doi: 10.1002/mds.26476, indexed in Pubmed: 26799362.

14. Beach TG, Adler CH, Dugger BN, et al. Arizona Parkinson's Disease Consortium. Submandibular gland biopsy for the diagnosis of Parkinson disease. J Neuropathol Exp Neurol. 2013; 72(2): 130-136, doi: 10.1097/NEN.0b013e3182805c72, indexed in Pubmed: 23334596.

15. Adler CH, Dugger BN, Hinni ML, et al. Submandibular gland needle biopsy for the diagnosis of Parkinson disease. Neurology. 2014; 82(10): 858-864, doi: 10.1212/WNL.0000000000000204, indexed in Pubmed: 24500652.

16. Moher D, Liberati A, Tetzlaff J, et al. PRISMA Group, PRISMA Group, PRISMA Group, PRISMA Group, PRISMA Group, PRISMA Group, PRISMA Group. Preferred reporting items for systematic reviews and meta-analyses: the PRISMA Statement. Open Med. 2009; 3(3): e123e130, indexed in Pubmed: 21603045.

17. Devic I, Hwang H, Edgar JS, et al. Salivary $\alpha$-synuclein and DJ-1: potential biomarkers for Parkinson's disease. Brain. 2011; 134(Pt 7): e178, doi: 10.1093/brain/awr015, indexed in Pubmed: 21349902.

18. Stewart T, Sui YT, Gonzalez-Cuyar LF, et al. Cheek cell-derived $\alpha$-synuclein and DJ-1 do not differentiate Parkinson's disease from control. Neurobiol Aging. 2014; 35(2): 418-420, doi: 10.1016/j.neurobiolaging.2013.08.008, indexed in Pubmed: 24041968.

19. Spillantini MG, Schmidt ML, Lee VM, et al. Alpha-synuclein in Lewy bodies. Nature. 1997; 388(6645): 839-840, doi: 10.1038/42166, indexed in Pubmed: 9278044.

20. Spillantini MG, Crowther RA, Jakes R, et al. alpha-Synuclein in filamentous inclusions of Lewy bodies from Parkinson's disease and dementia with lewy bodies. Proc Natl Acad Sci U S A. 1998; 95(11): 6469-6473, doi: 10.1073/pnas.95.11.6469, indexed in Pubmed: 9600990.
21. Baba M, Nakajo S, Tu PH, et al. Aggregation of alpha-synuclein in Lewy bodies of sporadic Parkinson's disease and dementia with Lewy bodies. Am J Pathol. 1998; 152(4): 879-884, indexed in Pubmed: 9546347.

22. Vivacqua G, Latorre A, Suppa A, et al. Abnormal Salivary Total and Oligomeric Alpha-Synuclein in Parkinson's Disease. PLoS One. 2016; 11(3): e0151156, doi: 10.1371/journal.pone.0151156, indexed in Pubmed: 27011009.

23. Vivacqua G, Suppa A, Mancinelli R, et al. Salivary alpha-synuclein in the diagnosis of Parkinson's disease and Progressive Supranuclear Palsy. Parkinsonism Relat Disord. 2019; 63: 143-148, doi: 10.1016/j. parkreldis.2019.02.014, indexed in Pubmed: 30796010.

24. Al-Nimer MSM, Mshatat SF, Abdulla HI. Saliva $\alpha$-Synuclein and A High Extinction Coefficient Protein: A Novel Approach in Assessment Biomarkers of Parkinson's Disease. N Am J Med Sci. 2014; 6(12): 633-637, doi: 10.4103/1947-2714.147980, indexed in Pubmed: 25599051.

25. Goldman JG, Andrews H, Amara A, et al. Fox Investigation of New Biomarker Discovery. Cerebrospinal fluid, plasma, and saliva in the BioFIND study: Relationships among biomarkers and Parkinson's disease Features. Mov Disord. 2018; 33(2): 282-288, doi: 10.1002/ mds.27232, indexed in Pubmed: 29205509.

26. Kang $\mathrm{W}$, Chen $\mathrm{W}$, Yang $\mathrm{Q}$, et al. Salivary total $\alpha$-synuclein, oligomeric $\alpha$-synuclein and SNCA variants in Parkinson's disease patients. Sci Rep. 2016; 6: 28143, doi: 10.1038/srep28143, indexed in Pubmed: 27335051.

27. Cao Z, Wu Y, Liu G, et al. $\alpha$-Synuclein in salivary extracellular vesicles as a potential biomarker of Parkinson's disease. Neurosci Lett. 2019; 696: 114-120, doi: 10.1016/j.neulet.2018.12.030, indexed in Pubmed: 30579996.

28. Zhang Li, Shimoji M, Thomas B, et al. Mitochondrial localization of the Parkinson's disease related protein DJ-1: implications for pathogenesis. Hum Mol Genet. 2005; 14(14): 2063-2073, doi: 10.1093/hmg/ ddi211, indexed in Pubmed: 15944198.

29. Kang WY, Yang $Q$, Jiang XF, et al. Salivary DJ-1 could be an indicator of Parkinson's disease progression. Front Aging Neurosci. 2014; 6: 102, doi: 10.3389/fnagi.2014.00102, indexed in Pubmed: 24936184.

30. Masters J, Noyce A, Lynham S, et al. comprehensive characterisation of the salivary proteome of patients with Parkinson's disease. 20th International Congress of Parkinson's Disease and Movement Disorders. ; 2016.

31. Skogar O, Fall PA, Hallgren G, et al. Diurnal salivary cortisol concentrations in Parkinson's disease: increased total secretion and morning cortisol concentrations. Int J Gen Med. 2011; 4: 561-569, doi: 10.2147/IJGM.S20875, indexed in Pubmed: 21887109.

32. Costa CM, Oliveira GL, Fonseca AC, et al. Levels of cortisol and neurotrophic factor brain-derived in Parkinson's disease. Neurosci Lett. 2019; 708: 134359, doi: 10.1016/j.neulet.2019.134359, indexed in Pubmed: 31265872.

33. Djamshidian A, O'Sullivan SS, Papadopoulos A, et al. Salivary cortisol levels in Parkinson's disease and its correlation to risk behaviour. J Neurol Neurosurg Psychiatry. 2011; 82(10): 1107-1111, doi: 10.1136/jnnp.2011.245746, indexed in Pubmed: 21478206.

34. Bolitho SJ, Naismith SL, Rajaratnam SMW, et al. Disturbances in melatonin secretion and circadian sleep-wake regulation in Parkinson disease. Sleep Med. 2014; 15(3): 342-347, doi: 10.1016/j. sleep.2013.10.016, indexed in Pubmed: 24529544.

35. Schröder JB, Marian T, Claus I, et al. Substance P Saliva Reduction Predicts Pharyngeal Dysphagia in Parkinson's Disease. Front Neurol. 2019; 10: 386, doi: 10.3389/fneur.2019.00386, indexed in Pubmed: 31040820. 
36. Fedorova T, Knudsen CS, Mouridsen $\mathrm{K}$, et al. Salivary acetylcholinesterase activity is increased in Parkinson's disease: a potential marker of parasympathetic dysfunction. Parkinsons Dis. 2015; 2015: 156479, doi: 10.1155/2015/156479, indexed in Pubmed: 25767737.

37. Huskić J, Paperniku A, Husić A, et al. Significantly reduced salivary nitric oxide synthesis in patients with Parkinson's disease. Bosn J Basic Med Sci. 2005; 5(3): 86-89, doi: 10.17305/bjbms.2005.3277, indexed in Pubmed: 16351589.

38. Song W, Kothari V, Velly AM, et al. Evaluation of salivary heme oxygenase-1 as a potential biomarker of early Parkinson's disease. Mov Disord. 2018; 33(4): 583-591, doi: 10.1002/mds.27328, indexed in Pubmed: 29488275.

39. Bermejo-Pareja F, Antequera D, Vargas T, et al. Saliva levels of Abeta1-42 as potential biomarker of Alzheimer's disease: a pilot study. BMC Neurol. 2010; 10: 108, doi: 10.1186/1471-2377-10-108, indexed in Pubmed: 21047401.

40. Chuang YH, Paul KC, Bronstein JM, et al. Parkinson's disease is associated with DNA methylation levels in human blood and saliva. Genome Med. 2017; 9(1): 76, doi: 10.1186/s13073-017-0466-5, indexed in Pubmed: 28851441.

41. Kalia LV, Kalia SK, McLean PJ, et al. $\alpha$-Synuclein oligomers and clinical implications for Parkinson disease. Ann Neurol. 2013; 73(2): 155-169, doi: 10.1002/ana.23746, indexed in Pubmed: 23225525.

42. Roberts RF, Wade-Martins R, Alegre-Abarrategui J. Direct visualization of alpha-synuclein oligomers reveals previously undetected pathology in Parkinson's disease brain. Brain. 2015; 138(Pt 6): 1642-1657, doi: 10.1093/brain/awv040, indexed in Pubmed: 25732184.

43. Zhou Bo, Wen M, Yu WF, et al. The Diagnostic and Differential Diagnosis Utility of Cerebrospinal Fluid $\alpha$-Synuclein Levels in Parkinson's Disease: A Meta-Analysis. Parkinsons Dis. 2015; 2015: 567386, doi: 10.1155/2015/567386, indexed in Pubmed: 26336612.

44. Hamm-Alvarez SF, Okamoto CT, Janga SR, et al. Oligomeric $\alpha$-synuclein is increased in basal tears of Parkinson's patients. Biomark Med. 2019; 13(11): 941-952, doi: 10.2217/bmm-2019-0167, indexed in Pubmed: 31262201.

45. Fall PA, Saleh A, Fredrickson M, et al. Survival time, mortality, and cause of death in elderly patients with Parkinson's disease: a 9-year follow-up. Mov Disord. 2003; 18(11): 1312-1316, doi: 10.1002/ mds.10537, indexed in Pubmed: 14639673.

46. Gomar-Vercher S, Simón-Soro A, Montiel-Company JM, et al. Stimulated and unstimulated saliva samples have significantly different bacterial profiles. PLoS One. 2018; 13(6): e0198021, doi: 10.1371/ journal.pone.0198021, indexed in Pubmed: 29856779.

47. Hong Z, Shi M, Chung KA, et al. DJ-1 and alpha-synuclein in human cerebrospinal fluid as biomarkers of Parkinson's disease. Brain. 2010; 133(Pt 3): 713-726, doi: 10.1093/brain/awq008, indexed in Pubmed: 20157014.

48. Barbe AG, Heinzler A, Derman S, et al. Hyposalivation and xerostomia among Parkinson's disease patients and its impact on quality of life. Oral Dis. 2017; 23(4): 464-470, doi: 10.1111/odi.12622, indexed in Pubmed: 27976483. 